\title{
Using stable isotopes and major ions to investigate the interaction between shallow and deep groundwater in Baiyangdian Lake Watershed, North China Plain
}

\author{
Jie Zhang ${ }^{1}$, Maki Tsujimura ${ }^{1}$, Xianfang Song ${ }^{2}$ and Koichi Sakakibara ${ }^{1}$ \\ ${ }^{I}$ Graduate School of Life and Environmental Sciences, University of Tsukuba, Japan \\ ${ }^{2}$ Institute of Geographic Sciences and Natural Resources Research, Chinese Academy of Sciences, China
}

\begin{abstract}
:
In arid/semi-arid regions, consumption of deep groundwater resources is increasing due to growing water demand in every sector. Intensive groundwater surveys focused on the Baiyangdian Lake Watershed (BLW) in the northwest of the North China Plain, as the BLW suffers from serious water problems due to high economic growth and improper groundwater resource utilization.

To clarify the interaction between shallow and deep groundwater, samples of surface water and groundwater in different aquifers were collected from two cities (Baoding City and Dingzhou City). Major trace element solute ion concentrations and stable isotopes of $\delta^{18} \mathrm{O}$ and $\delta^{2} \mathrm{H}$ revealed that, in a specific region of Baoding, anthropogenic activities have induced interaquifer recharge from Aquifer 1 to Aquifer 2 based on the similarity in chemical tracers. However, such an interaction could not be found in other regions in the study area.
\end{abstract}

KEYWORDS interaction; shallow groundwater; deep groundwater; Baiyangdian Lake Watershed

\section{INTRODUCTION}

It has been recognized that deep groundwater has better properties than shallow groundwater, such as steady and sufficient yield and better water quality. As a result, deep groundwater consumption has grown rapidly throughout the world in recent years, especially in arid and semi-arid regions where deep groundwater has become the main water resource for social and economic sectors (Seiler and Lindner, 1995; UNESCO, 2009, 2012). Seiler and Lindner (1995) explained that deep groundwater has a longer flow path and residence time compared with shallow groundwater, because it is buried in deeper confined aquifers. This also suggests that once deep groundwater is contaminated, it creates a more severe environmental problem because it is more difficult to restore the water stored in deeper aquifers.

Aquifer-scale interaction estimates are essential for groundwater resource management (Scanlon and Cook, 2002). However, limited research concerning the interaquifer recharge between shallow and deep aquifers exists. Seiler and Lindner (1995), and Wang (1995) emphasized that this recharge may occur even if there is aquitard or aquiclude existing between the shallow and deep aquifers. Carucci et

Correspondence to: Jie Zhang, Graduate School of Life and Environmental Sciences, University of Tsukuba, Tsukuba, Ibaraki 305-8572, Japan. E-mail: jeokey121@hotmail.com al. (2012) reported that the ratio of interaquifer recharge in the Tivoli Plain (Central Italy) is about $48 \sim 62 \%$ of the total recharge in the area.

Problems will occur if shallow groundwater, which is polluted and not suitable for drinking, recharges deep groundwater (Wang, 1995). What is worse is when these two conditions co-exist, i.e., shallow groundwater pollution forces people to extract groundwater from a deep aquifer, and, consequently, the shallow groundwater table rises above the deep groundwater head, which enhances the recharge between different aquifers. Some researchers have reported cases of intrusion of shallow groundwater into deep groundwater due to an overexploitation of the deep groundwater in, for example, China, Thailand and India, although strong evidence (i.e., stable isotopes analysis) were not supplied in these studies (Guo and Shen, 1995; Onodera et al., 2009; Saha et al., 2011).

The North China Plain (NCP) is well known as one of the most developed industrial areas and one of the largest agricultural production areas in China (Sun et al., 2010). A lot of research is focused here because intensive and improper groundwater development in this area has caused many problems. Fang et al. (2010) and Shu et al. (2012) proposed some methods for improving water use efficiency by using a hydrological model and assessing spatial and temporal availability of water resources in the NCP. However, other research was concerned with hydrochemical groundwater characteristics and processes in the NCP (e.g., Hu et al., 2005; Wang et al., 2008; Yuan et al., 2011; Xing et al., 2013), as serious pollution problems in the shallow groundwater are mentioned frequently.

The assessment of the degree of deep groundwater exploitation in NCP showed that deep groundwater in most areas is being over-exploited (Shi et al., 2011). In the vicinity of Baoding (the biggest city in the Baiyangdian Lake Watershed; BLW), the deep groundwater head was found to be below the shallow groundwater table based on a geological investigation by Zhang and Fei (2009). Under such conditions, there is a high possibility that interaquifer recharge from the shallow aquifer to deep aquifer occurs. In fact, by using a numerical simulation model, Cao (2013) reported that lateral flow to the deep aquifer in NCP is limited and the primary inflow to the deep aquifer is downward, suggesting interaquifer recharge from the shallow aquifer. However, this result has not been verified by direct field observations (e.g., water sampling and geochemical analysis).

Received 25 February, 2016 Accepted 29 April, 2016 Published online 7 June, 2016 
Groundwater isotopes combined with chemistry can produce a more reliable conceptual model of a groundwater flow system (e.g., Tsujimura et al., 2007; Chkirbene et al., 2009). Specifically, due to the efficiency and economy, stable isotopes combined with major ions are prior to be used in clarifying the primary hydrogeological situation for one objective area. In this study, the authors investigate the possibility and characteristics of the interaction between shallow and deep groundwater in the study area using major ions and stable isotopes with a view to sustainable groundwater resource management.

\section{STUDY AREA}

Located in the northwest part of the NCP, the BLW covers an area of about $36,000 \mathrm{~km}^{2}$ (Figure 1), and has an urban population of over 12 million (Juana et al., 2010). Baoding City, with a population of over 8 million, is the largest city in this area (Figure 1). Baiyangdian Lake, the largest fresh lake of the NCP with an area of $366 \mathrm{~km}^{2}$ is located in southeast part of BLW (Figure 1). The elevation inclines towards the northwest, from the southeast plains to the Taihang mountainous area, with elevation ranging from around 5.5 6.0 m at the bottom of Baiyangdian Lake to $2,088 \mathrm{~m}$. The mountainous areas (above $100 \mathrm{~m}$ a.s.1.) occupy approximately $53 \%$ of this watershed (Long et al., 2010; Figure 2).

The study area has a continental climate, which is predominantly influenced by continental monsoon winds, with distinct seasonality. The average temperature in the coldest month of January is $-11^{\circ} \mathrm{C}$ compared to $27^{\circ} \mathrm{C}$ in the hottest month of July. Average annual temperature, precipitation, and lake evaporation are $12^{\circ} \mathrm{C}, 581 \mathrm{~mm}$, and $1,581 \mathrm{~mm}$, respectively. Around $60 \sim 75 \%$ of precipitation falls in the summer months of July to August (Li and Zheng, 2001; Yang and Tian, 2009).

Hydrogeological conditions are represented in profile along an A-A' line across the plain area (Figure 3; see cross section in Figure 1). The unconsolidated Quaternary Q4 sediments constitute the main stratigraphy of the plain area, and these sediments mainly include sand, clay or silt clay, and silt. According to its stratigraphic features, the aquifer can be

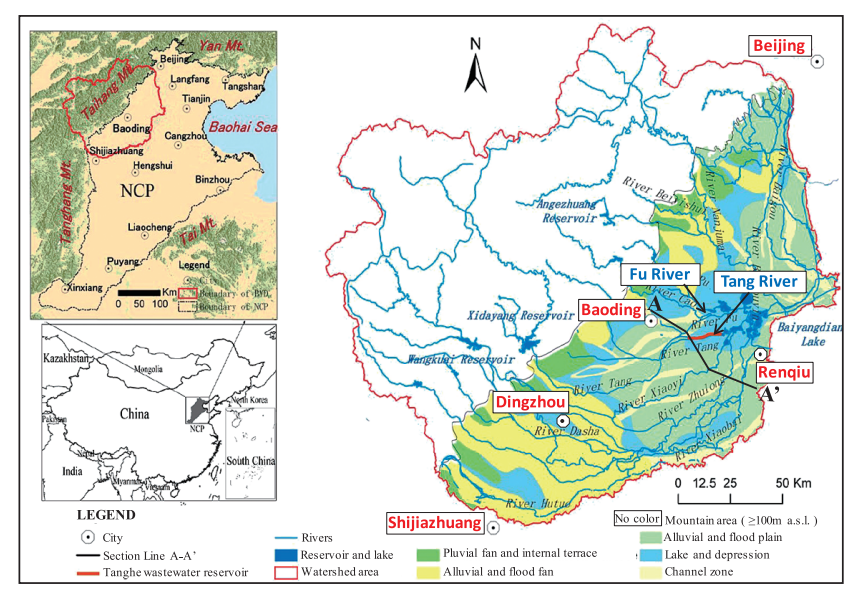

Figure 1. Location and major geological formation of the study area divided into four aquifer groups (see "Aquifer boundary" line in Figure 3). However, due to the thickness of the first unconfined aquifer and strong hydraulic connection, the first and second aquifers are usually considered as one aquifer group (Chen et al., 2005; Wang et al., 2014). As a result, along the A-A' profile near Baoding, the first aquifer group (Aquifer 1) includes aquifers of Holocene Qh and upper Pleistocene Qp3 with depth of 60 120 m. The second aquifer group (Aquifer 2) is the Middle Pleistocene Qp2 aquifer with depth of 120 360 m along A-A' line. The third aquifer group (Aquifer 3) is the lower Pleistocene Qp1 aquifer.

Regional shallow and deep groundwater levels have been compiled by Zhang and Fei (2009; Figure 2). The main flow direction of both shallow and deep groundwater is roughly from the north and south of the plain area towards Baiyangdian Lake. Especially, in the southeast area of

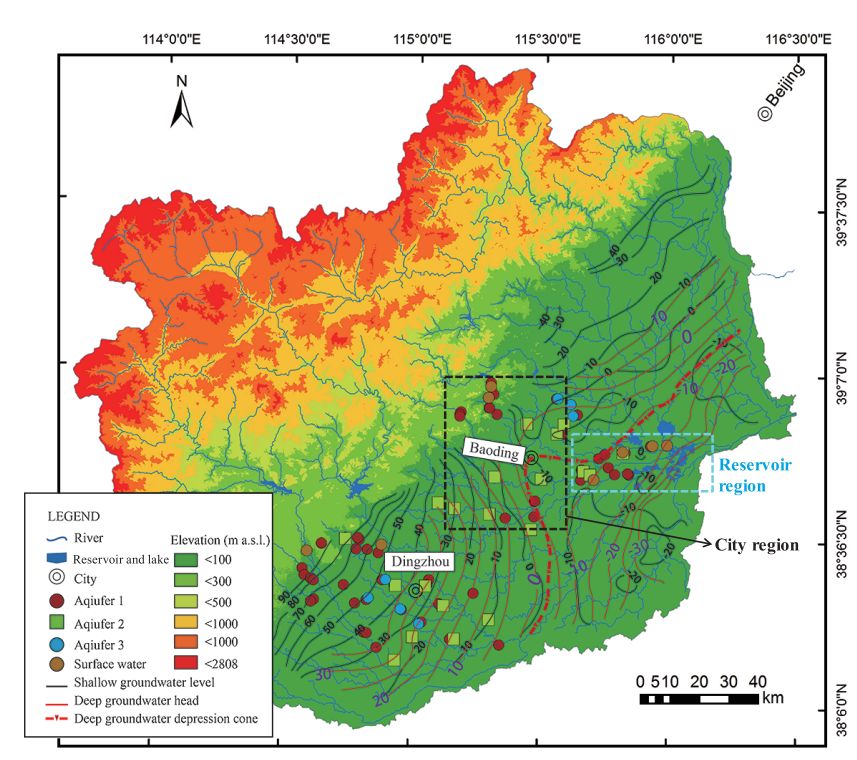

Figure 2. Sampling locations, topographic information (data source: http://gdem.ersdac.jspacesystems.or.jp), and shallow and deep groundwater levels in the study area based on previous investigation results (Zhang and Fei, 2009)

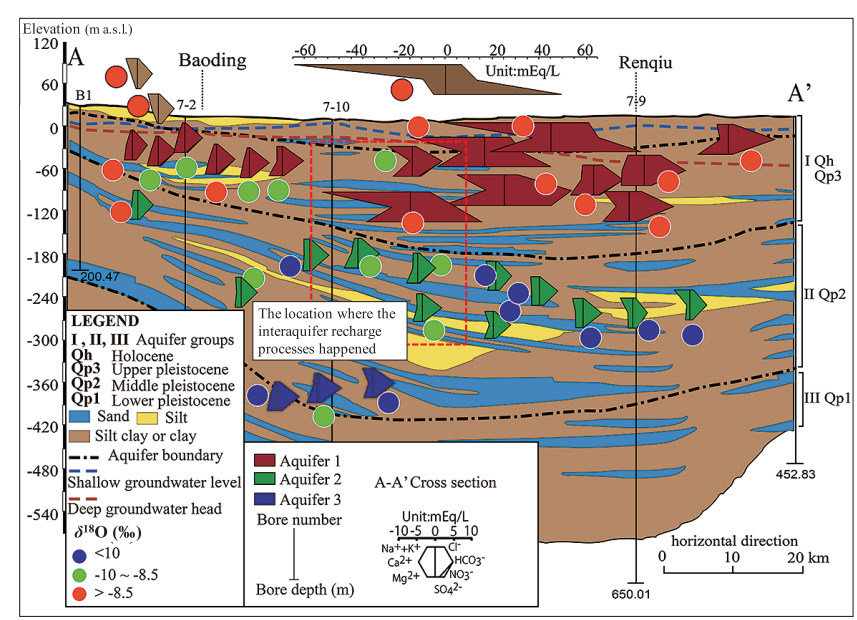

Figure 3. Hydrogeological setting, Stiff diagram, $\delta^{18} \mathrm{O}$ value distribution profile along the A-A' cross-section of Figure 1 
Baoding, the deep groundwater hydraulic head begins to fall below the shallow groundwater level, and then forms a deep groundwater depression cone region.

\section{METHODS}

In total, 91 groundwater samples and 8 surface water samples were collected from the three field surveys in the BLW plain area from 2011 to 2012. The sample sites are mainly located around two cities, Baoding and Dingzhou, which are the two major cities in the study area (Figure 2). The samples from Baoding area were collected in June 2011 and March 2012. In particular, 4 of 8 surface water samples were collected along the Fu River and the Tang River (see reservoir region, Figure 2), both of which are now used as sewage reservoirs for waste water from Baoding. The samples in the Dingzhou area were collected in August 2012. The well depth information was obtained from local villagers. Based on depth, elevation, and stratigraphic condition, groundwater samples were divided into three groups (Aquifers 1, 2, and 3 ) according to the aquifer group they belong to. Based on the information from local villagers, for accessing safe water resources, the government helped to drill the deep well. So it is assumed that these deep wells have good enough structure and quality to prevent the leakage from shallow aquifer to deep aquifer.

The temperature (Nikkyo Technos Co. Ltd., Petten Kocher), electrical conductivity (EC; HORIBA Ltd., Twin Cond B173) and pH value (HORIBA Ltd., Twin PH Meter B121) of the water samples were measured in situ. The location of all sampling points was determined by a portable GPS meter (GARMIN Ltd., GPSMAP 76S). Each sample was placed and sealed in a $100 \mathrm{~mL}$ polyethylene bottle and transported to the University of Tsukuba, Japan for chemical and isotopic composition analysis. The chemical composition was characterized by an ion chromatography analyzer (Shimazu Co. Ltd., HIC-SP/VP Super) for major anions $\left(\mathrm{Cl}^{-}, \mathrm{NO}_{3}^{-}, \mathrm{SO}_{4}^{2-}\right)$ and an inductively coupled plasma atomic emission spectrometer (PerkinElmer Inc., Optima 7300DV) for major cations $\left(\mathrm{K}^{+}, \mathrm{Na}^{+}, \mathrm{Ca}^{2+}\right.$, and $\left.\mathrm{Mg}^{2+}\right)$. Bicarbonate $\left(\mathrm{HCO}_{3}^{-}\right)$concentration was measured using a titration method with sulfuric acid as soon as the samples were taken back to the laboratory. The stable isotopes of $\delta^{18} \mathrm{O}$ and $\delta^{2} \mathrm{H}$ were measured with a mass spectrometer (Finnigan Inc., MAT 252). The $\delta^{18} \mathrm{O}$ and $\delta^{2} \mathrm{H}$ values are reported as per mill $(\%)$ deviations from the international standard Vienna Standard Mean Ocean Water (V-SMOW). The analytical errors were $0.1 \%$ or for $\delta^{18} \mathrm{O}$ and $1 \%$ for $\delta^{2} \mathrm{H}$, respectively.

One more point that should be emphasized ahead of discussion is that, because water samples in the Baoding area were all taken in the dry season, while those in the Dingzhou area were all taken in rainy season, the seasonal change for each area will not be discussed in the paper.

\section{RESULTS AND DISCUSSION}

\section{Stable isotopes}

Stable isotopic compositions in groundwater are rarely affected by water-rock/soil ion exchange under normal temperatures, or by evaporation as long as they are under a cer- tain depth which is usually not too deep (McCarthy et al., 1992; Gat, 1996). Therefore, the stable isotopic variations existing in groundwater might be the consequence of the concentration variations from inputs such as precipitation and surface water (Kendall and McDonnell, 1998).

Figure 4 shows the relationship between $\delta^{2} \mathrm{H}$ and $\delta^{18} \mathrm{O}$ values of surface water and groundwater in the (a) Baoding and (b) Dingzhou areas with a local meteoric water line (LMWL) $\left(\delta^{2} \mathrm{H}=8.2 \delta^{18} \mathrm{O}+9.4\right.$; precipitation at Shijiazhuang in Figure 1; WMO/IAEA, 2003), which is quite close to the global meteoric water line (GMWL) $\left(\delta^{2} \mathrm{H}=8 \delta^{18} \mathrm{O}+10\right.$; Craig, 1961). The $\delta^{2} \mathrm{H}$ and $\delta^{18} \mathrm{O}$ values of LMWL were plotted using the weighted mean year values with a large variation ranging from $-11.13 \%$ to $-6.50 \%$ for $\delta^{18} \mathrm{O}$ values and from $-81.20 \%$ to $-39.73 \%$ for $\delta^{2} \mathrm{H}$ values.

In the Baoding area, the stable isotopic composition in surface water displayed the heaviest value ranging from $-7.60 \%$ to $-4.14 \%$ or for $\delta^{18} \mathrm{O}$ and $-56.35 \%$ to $-40.11 \%$ for $\delta^{2} \mathrm{H}$, and the slope of these samples was apparently lower than that of LMWL. This kind of enrichment is caused by isotopic fractionation during water evaporation (Craig et al., 1963). In this area, the stable isotopic compositions of

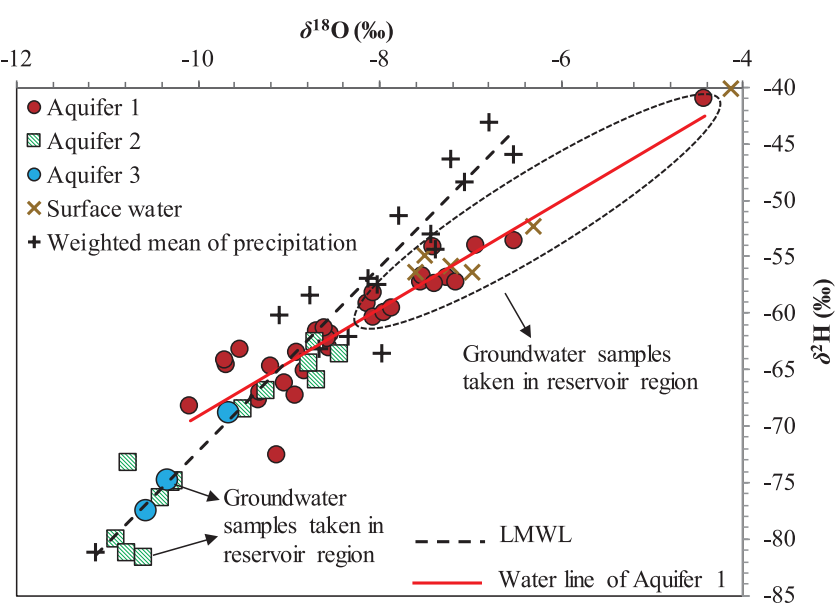

(a)

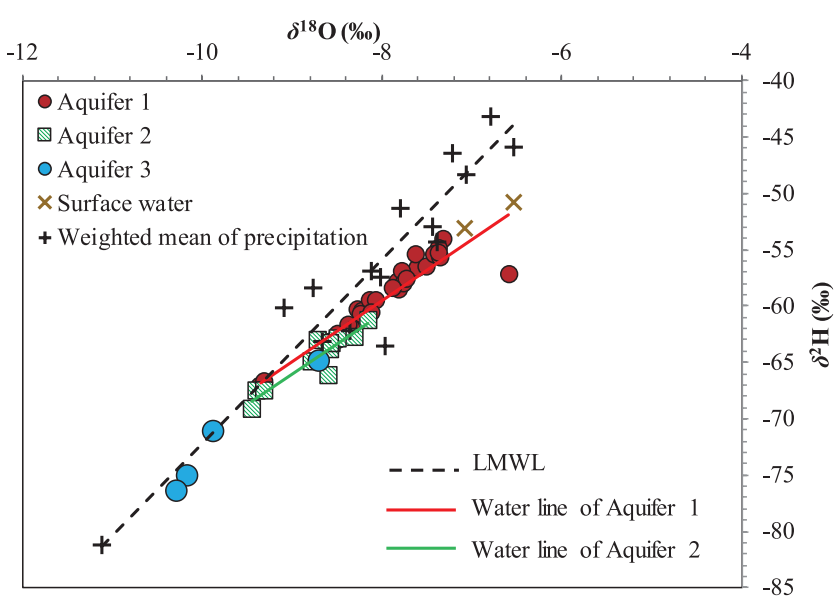

(b)

Figure 4. Relationship between $\delta^{18} \mathrm{O}$ and $\delta \mathrm{D}$ in water samples collected in the study areas; (a) Baoding area, (b) Dingzhou area 
groundwater samples in Aquifer 1, ranging from $-10.09 \%$ to $-4.42 \%$ for $\delta^{18} \mathrm{O}$ values and from $-68.29 \%$ o to $-40.94 \%$ for $\delta^{2} \mathrm{H}$ values, were relatively higher than those in Aquifer 2 and Aquifer 3. Although the slope of the water line of the Aquifer 1 samples $\left(\delta^{2} \mathrm{H}=4.8 \delta^{18} \mathrm{O}-21.4\right)$ was lower than that of LMWL, there is a set of Aquifer 1 samples close to the LMWL. Specifically, these samples which are away from LMWL are almost certainly from the reservoir region (Figures 2 and 4a). This suggests that parts of the samples from Aquifer 1 are affected by surface water, and the rest of these samples are recharged directly by precipitation without intensive evaporation processes. The groundwater samples in Aquifers 2 and 3 present stable isotopic compositions, ranging from $-10.91 \%$ to $-8.72 \%$ for $\delta^{18} \mathrm{O}$ values and from $-81.64 \%$ to $-62.56 \%$ for $\delta^{2} \mathrm{H}$ values in Aquifer 2, and from $-10.59 \%$ to $-9.68 \%$ o for $\delta^{18} \mathrm{O}$ values and from $-77.40 \%$ o to $-68.74 \%$ for $\delta^{2} \mathrm{H}$ values in Aquifer 3. Several samples in Aquifers 2 and 3 were mixed (Figure $4 \mathrm{a}$ ), which indicated that these samples from different aquifers probably originated from the same location. Other samples in Aquifer 2 were closer to the samples in Aquifer 1, which may imply an interaction (interaquifer recharge) process between these two aquifers; and this will be discussed in more detail later.

Similar to Baoding area, the surface water samples in Dingzhou area reflect a heavy value for stable isotopic composition, which may also be a consequence of water evaporation (Figure 4b). The Aquifer 1 samples in this area showed a relatively large variation in stable isotopic compositions, ranging from $-9.36 \%$ to $-6.59 \%$ for $\delta^{18} \mathrm{O}$ and from $-67.09 \%$ to $-57.26 \%$ or for $\delta^{2} \mathrm{H}$. The water line of these samples $\left(\delta^{2} \mathrm{H}=\right.$ $\left.5.4 \delta^{18} \mathrm{O}-16.2\right)$ represented a lower slope than the LMWL, and these samples were not close to the LMWL with the exception of one (DZ41, Figure 5b). This suggested that the groundwater in Aquifer 1 in the Dingzhou area probably did not originate from present-day precipitation but from some water body that experienced strong evaporation processes. The groundwater samples in Aquifer 2 of this area, with values ranging from $-9.40 \%$ to $-8.15 \%$ or $\delta^{18} \mathrm{O}$ and from $-67.62 \%$ to $-61.35 \%$ o for $\delta^{2} \mathrm{H}$, reflect mixing of Aquifer 1 and were far away from LMWL with the exception of one sample (DZ43, Figure 5b). This might imply another interaction process between the two aquifers similar to the Baoding area interaction. Nevertheless, the chemical composition showed a contrasting result (detailed discussion is presented in the following "Chemical composition" section). The groundwater samples from Aquifer 3 represented the lightest stable isotopic composition values in the Dingzhou area, and were well distributed along the LMWL except for one sample (DZ31, Figure 5b). This indicated that the groundwater in Aquifer 3 was recharged by precipitation infiltration at a relatively high elevation.

\section{Chemical composition}

Figure 5 shows the spatial distribution of the geochemical characteristics of all the samples in the Baoding and Dingzhou areas. The chemical composition of surface water and groundwater in Dingzhou area can be characterized as $\mathrm{Ca}-\mathrm{HCO}_{3}$ type with the exception of a few samples with a slight increase in sodium concentration (DZ31, DZ41, DZ43, and DZ44). Many samples with high nitrate concentration were also found upstream of this area, probably caused by fertilizers used in agriculture (Owens et al., 1992).

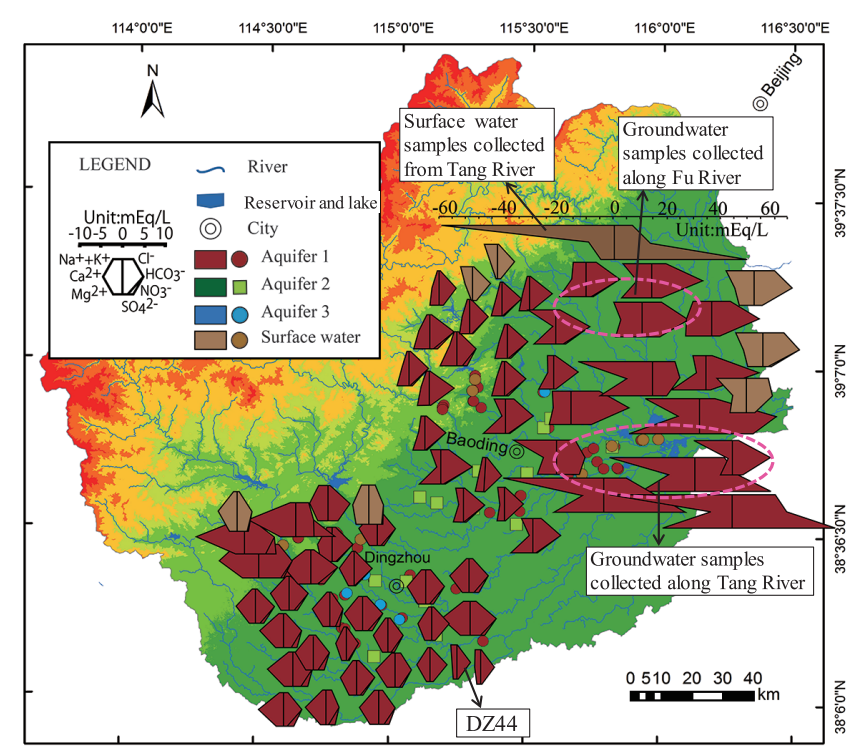

(a)

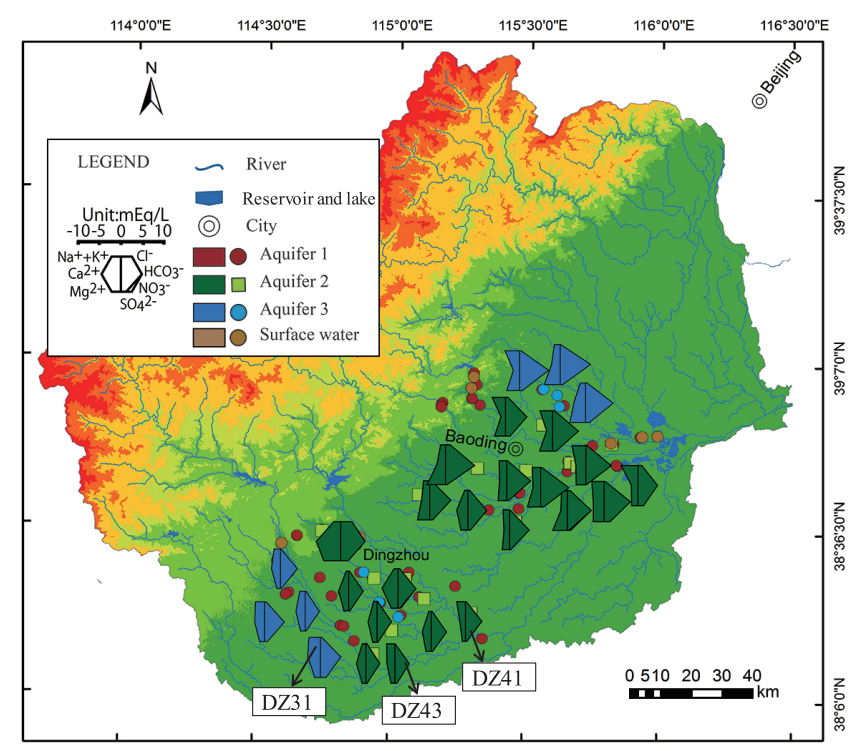

(b)

Figure 5. Spatial distribution of the chemical composition of the surface water and groundwater in study area; (a) results of Aquifer 1 and surface water, (b) results of Aquifers 2 and 3

The chemical composition situation in the Baoding area is more complicated. Affected by surface water, the groundwater samples in Aquifer 1 in the Baoding area cannot be characterized uniformly. However, many of these samples, which are far from the reservoir region, can still be characterized as a $\mathrm{Mg}-\mathrm{HCO}_{3}$ water type. The chemical composition of groundwater in Aquifers 2 and 3 from Baoding varied from $\mathrm{Na}-\mathrm{Mg}-\mathrm{HCO}_{3}$ to $\mathrm{Mg}-\mathrm{HCO}_{3}$ roughly along a northsouth orientation, which implies some $\mathrm{Na}-\mathrm{Mg}$ exchange reactions in this area.

A trilinear diagram is shown in Figure 6 for water samples of the (a) Baoding and (b) Dingzhou areas. Corresponding to the stable isotopic compositions, the groundwater in Aquifer 1 in Baoding taken from the reservoir region is chemically different from other groundwater in this area (Figure 6a). 


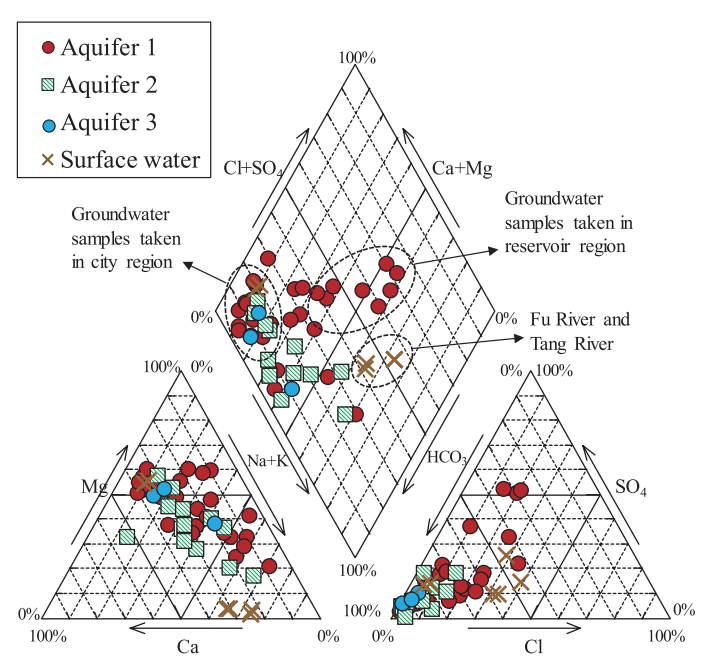

(a)

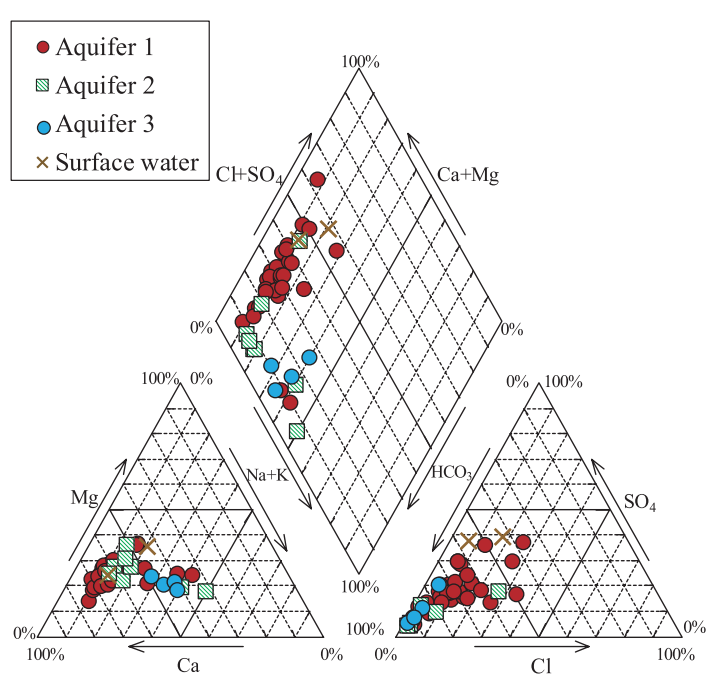

(b)

Figure 6. Trilinear diagram for the water samples collected in study areas; (a) Baoding area, (b) Dingzhou area

However, these samples did not coincide with the surface water, although the samples are close to the surface water in terms of stable isotopic compositions (Figure 4a). This suggests that these samples are affected by both surface water and precipitation. On the other hand, the rest of the groundwater in Aquifer 1 from this area is well mixed with groundwater from Aquifer 2, which further confirms the possibility of an interaquifer recharge process existing between these two aquifers in the Baoding area. For the Dingzhou area, groundwater samples in Aquifer 2 are not chemically similar to those in Aquifer 1, which is a result contrary to the stable isotopic compositions (Figure 4b).

\section{Interaction between shallow and deep groundwater}

Based on the stable isotope and geochemical composition results, the interaction between shallow and deep groundwater, specifically the interaquifer recharge processes from Aquifer 1 to Aquifer 2, can be found in the city region of

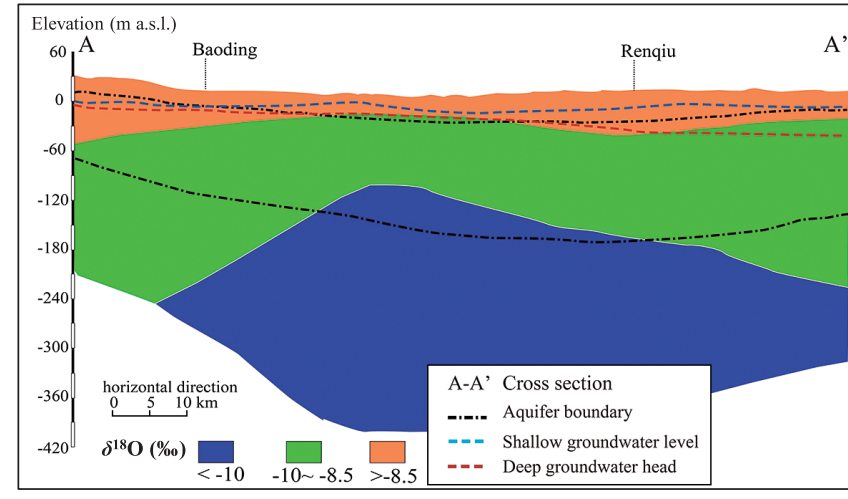

Figure 7. Investigation result of $\delta^{18} \mathrm{O}$ value distribution profile along A-A' cross-section of Figure 1 in 2005 (compiled based on previous investigation results by Zhang and Fei, 2009)

Baoding (Figure 2). Stable isotope analyses showed that the groundwater in Aquifer 2 could be divided into two parts (Figure 4a). One part represents light stable isotopic compositions and was close to Aquifer 3, and the other part was mixed with groundwater in Aquifer 1 and showed relatively heavy isotopic compositions. Although the groundwater in both Aquifers 1 and 2 of this region distributed along the LMWL, the variation in values suggested that they are recharged from precipitation infiltration at different elevations (Gat, 1980; Clark and Fritz, 1997). Therefore, such differentiation in the same aquifer can be explained by extra interaquifer recharge processes from a shallow aquifer. Not only the stable isotopic compositions, but also the geochemical results, show a mixing of Aquifer 1 groundwater with Aquifer 2 groundwater in the city region of Baoding (Figure $6 a)$. The spatial distribution of the stiff-diagram and $\delta^{18} \mathrm{O}$ values along the A-A' cross section for part of groundwater and surface water samples in Baoding is presented in Figure 3. The figure shows that the groundwater in Aquifer 2 with a $\delta^{18} \mathrm{O}$ value ranging from $-10 \%$ to $-8.5 \%$ reaches at depth of over $300 \mathrm{~m}$ in the region between Baoding and Renqiu (Figure 1) where the deep groundwater depression cone exists. However, according to a previous study by Zhang and Fei (2009), this numerical range $(-10 \%$ $-8.5 \%$ ) only extended to about $150 \mathrm{~m}$ below the surface in this region in 2005 (Figure 7). Such changes could be solid evidence for the interaquifer recharge processes between the shallow and deep groundwater in this region.

Nevertheless, the aforementioned interaction between shallow and deep groundwater was not found in other areas, namely the reservoir region in Baoding and the whole Dingzhou area. In the reservoir region in Baoding there is no doubt that surface water influences the groundwater in Aquifer 1 based on the results of stable isotopic and geochemical compositions. However, the groundwater in this aquifer does not transfer these influences downward, because neither the isotopic results (Figure 4a) or geochemical results (Figure 6a) showed similarity between the groundwater in Aquifers 2 and 1. The situation is a little bit different in Dingzhou area, where the stable isotopic composition and geochemical composition showed inverse results (Figures $3 \mathrm{~b}$ and $5 \mathrm{~b}$ ). The former shows that groundwater in Aquifer 2 
Table I. The interaction relationship between different aquifers in study area

\begin{tabular}{cccc}
\hline & \multicolumn{2}{c}{ Baoding area } & Dingzhou area \\
\cline { 2 - 3 } & city region & other regions & \\
\hline Aquifer 1 & existent & non-existent & non-existent \\
Aquifer 2 & non-existent & non-existent & non-existent \\
Aquifer 3 & & & \\
\hline
\end{tabular}

mixes with that in Aquifer 1, which implied an interaction between them, while the latter indicates that the groundwater in Aquifer 2 was chemically dissimilar to that of Aquifer 1. Therefore, interaction did not exist between these two aquifers. Similar characteristics in terms of stable isotope compositions could be explained by recharge resources with similar stable isotope characteristics.

\section{CONCLUSIONS}

As a crucially important water resource in the North China Plain, deep groundwater is now widely used but improper exploitation occurs within the study area. As seriously polluted shallow groundwater has a high possibility of recharging deep aquifer, this study investigated the interaction between shallow and deep groundwater around Baoding City and Dingzhou City using major ions and stable isotopes. Under the assumption that deep wells are of reliably good quality and thus prevent leakage from shallow aquifers, the results clearly show the interaction relationship between different aquifers (Table I). The interaquifer recharge processes from Aquifer 1 (shallow aquifer) to Aquifer 2 (deep aquifer) were confirmed to exist in the city region of Baoding, as the samples from Aquifer 2 coincide with the samples from Aquifer 1, both chemically and isotopically. However, due to considerable differences between Aquifer 1 samples and Aquifer 2 samples from the reservoir region of Baoding area, a similar interaction is not supported. In Dingzhou area, although groundwater samples from Aquifer 2 showed similar stable isotopic characteristics as those of Aquifer 1, the differences in geochemical compositions suggest that an interaction between shallow and deep groundwater may not exist in this area.

Further work should focus on taking more water samples in the city region of Baoding area for analysis of stable isotopes and major ions. Based on sufficient water samples, the contribution ratio and amount of interaquifer recharge can be statistically calculated, which will provide important information for groundwater resources policy makers.

\section{REFERENCES}

Cao GL. 2013. Evaluation of groundwater system in the North China Plain using groundwater modelling. Doctoral Dissertation, China University of Geosciences; 113 (in Chinese with English abstract).

Carucci V, Petitta M, Aravena R. 2012. Interaction between shallow and deep aquifers in the Tivoli Plain (Central Italy) enhanced by groundwater extraction: A multi-isotope approach and geochemical modeling. Applied Geochemistry 27: 266-280. DOI: 10.1016/j.apgeochem.2011.11.007.

Chen ZY, Nie ZL, Zhang ZJ, Qi JX, Nan YJ. 2005. Isotopes and sustainability of ground water resources, North China Plain. Groundwater 43: 485-493. DOI: 10.1111/j.1745-6584.2005. 0038.x.

Chkirbene A, Tsujimura M, Charef A, Tanaka T. 2009. Hydrogeochemical evolution of groundwater in an alluvial aquifer: Case of Kurokawa aquifer, Tochigi prefecture, Japan. Desalination 246: 485-495. DOI: 10.1016/j.desal.2008.04.057.

Clark I, Fritz P. 1997. Environmental Isotopes in Hydrogeology, CRC Press, Boca Raton, USA; 342.

Craig H. 1961. Isotopic variations in meteoric waters. Science 133: 1702-1703. DOI: 10.1126/science.133.3465.1702.

Craig H, Gordon LI, Horibe Y. 1963. Isotopic exchange effects in the evaporation of water: 1 . Low-temperature experimental results. Journal of Geophysical Research 68: 5079-5087. DOI: 10.1029/JZ068i017p05079.

Fang QX, Mab L, Green TR, Yu Q, Wang TD, Ahujab LR. 2010. Water resources and water use efficiency in the North China Plain: Current status and agronomic management options. Agricultural Water Management 97: 1102-1116. DOI: 10.1016 /j.agwat.2010.01.008.

Gat JR. 1980. Handbook of Environmental Isotope Geochemistry. In The Isotopes of Hydrogen and Oxygen in Precipitation, Fritz P, Fontes JC (eds). Elsevier: Amsterdam, the Netherlands; 21-47.

Gat JR. 1996. Oxygen and hydrogen isotopes in the hydrologic cycle. Annual Review of Earth and Planetary Sciences 24: 225-262. DOI: 10.1146/annurev.earth.24.1.225.

Guo YH, Shen ZL. 1995. Relationship between saline water downgoing and desalination of shallow saline water, Hebei Plain. Hydrogeology and Engineering Geology 2: 8-12 (in Chinese with English abstract).

Hu KL, Huang YF, Li H, Li BG, Chen DL, White RE. 2005. Spatial variability of shallow groundwater level, electrical conductivity and nitrate concentration, and risk assessment of nitrate contamination in North China Plain. Environment International 31: 896-903. DOI: 10.1016/j.envint.2005.05.028.

Juana PM, Yang YH, Li HL. 2010. Impact of water resource exploitation on the hydrology and water storage in Baiyangdian Lake. Hydrological Processes 24: 3026-3039. DOI: 10.1002/hyp. 7716.

Kendall C, McDonnell JJ. 1998. Isotope Tracers in Catchment Hydrology. Elsevier Science, Amsterdam, the Netherlands; 839.

Li L, Zheng H. 2001. Environmental and ecological water requirements of a river system: a case study of the Haihe-Luanhe River System. Journal of Geographical Sciences 11: 224 230. DOI: $10.1007 / \mathrm{BF} 02888694$.

Long D, Gao YC, Vijay PS. 2010. Estimation of daily average net radiation from MODIS data and DEM over the Baiyangdian Watershed in north China for clear sky days. Journal of Hydrology 388: 217-233. DOI: 10.1016/j.jhydrol.2010.04. 042.

McCarthy KA, McFarland WD, Wilkinson JM, White LD. 1992. The dynamic relationship between ground water and the Columbia River: using deuterium and oxygen-18 as tracers. Journal of Hydrology 135: 1-12. DOI: 10.1016/0022-1694 (92)90078-A.

Onodera S, Saito M, Sawano M, Hosono T, Taniguchi M, Shimada J, Umezawa Y, Lubis RF, Buapeng S, Delino R. 2009. Effects 
of intensive urbanization on the intrusion of shallow groundwater into deep groundwater: Examples from Bangkok and Jakarta. Science of the Total Environment 404: 401-410. DOI: 10.1016/j.scitotenv.2008.08.003.

Owens L, Edwards W, Van Keuren R. 1992. Nitrate levels in shallow groundwater under pastures receiving ammonium nitrate or slow-release nitrogen fertilizer. Journal of Environmental Quality 21: 607-613. DOI: 10.2134/jeq1992.0047242500 2100040014x.

Saha D, Sinha UK, Dwivedi SN. 2011. Characterization of recharge processes in shallow and deeper aquifers using isotopic signatures and geochemical behavior of groundwater in an arsenicenriched part of the Ganga Plain. Applied Geochemistry 26: 432-443. DOI: 10.1016/j.apgeochem.2011.01.003.

Scanlon BR, Cook PG. 2002. Theme issue on groundwater recharge. Hydrogeology Journal 10: 3-4. DOI: 10.1007/ s10040-001-0175-3.

Seiler KP, Lindner W. 1995. Near-surface and deep groundwaters. Journal of Hydrology 165: 33-44. DOI: 10.1016/00221694(94)02584-X.

Shi JS, Zhao W, Zhang ZJ, Fei YH, Li YS, Zhang FE, Chen JS, Qian Y. 2011. Assessment of deep groundwater overexploitation in the North China Plain. Geoscience Frontiers 2: 593-598. DOI: 10.1016/j.gsf.2011.07.002.

Shu YQ, Villholth KG, Jensen KH, Stisen S, Lei YP. 2012. Integrated hydrological modeling of the North China Plain: Options for sustainable groundwater use in the alluvial plain of Mt. Taihang. Journal of Hydrology 464-465: 79-93. DOI: 10.1016/j.jhydrol.2012.06.048.

Sun H, Shen Y, Yu Q, Flerchinger GN, Zhang Y, Liu C, Zhang X. 2010. Effect of precipitation change on water balance and WUE of the winter wheat-summer maize rotation in the North China Plain. Agricultural Water Management 97: 11391145. DOI: 10.1016/j.agwat.2009.06.004.

Tsujimura M, Abe Y, Tanaka T, Shimada J, Higuchi S, Yamanaka T, Davaa G, Oyunbaatar D. 2007. Stable isotopic and geochemical characteristics of groundwater in Kherlen River basin, a semi-arid region in eastern Mongolia. Journal of Hydrology 333: 47-57. DOI: 10.1016/j.jhydrol.2006.07.026.
UNESCO. 2009. Water in a Changing World: The United Nations World Development Report 3. UNESCO and Berghahn Books, Paris and London, France and UK; 318.

UNESCO. 2012. Managing Water under Uncertainty and Risk: The United Nations World Development Report 4. UNESCO and Berghahn Books, Paris and London, France and UK; 866.

Wang BG, Jin MG, Nimmo JR, Yang L, Wang WF. 2008. Estimating groundwater recharge in Hebei Plain, China under varying land use practices using tritium and bromide tracers. Journal of Hydrology 356: 209-222. DOI: 10.1016/j.jhydrol.2008. 04.011.

Wang DC. 1995. An Introduction to Hydrogeology. Geology Press, Beijing, China; 164 (in Chinese).

Wang SQ, Tang CY, Song XF, Wang QX, Zhang YH, Yuan RQ. 2014. The impacts of a linear wastewater reservoir on groundwater recharge and geochemical evolution in a semi-arid area of the Lake Baiyangdian watershed, North China Plain. Science of the Total Environment 482-483: 325-335. DOI: 10.1016/j.scitotenv.2014.02.130.

WMO/IAEA. 2013. Global Network of Isotopes in Precipitation database (GNIP database). http://www-naweb.iaea.org/napc/ ih/IHS_resources_gnip.html. Last access June 7, 2015.

Xing LN, Guo HM, Zhan YH. 2013. Groundwater hydrochemical characteristics and processes along flow paths in the North China Plain. Journal of Asian Earth Sciences 70-71: 250264. DOI: $10.1016 /$ j.jseaes.2013.03.017.

Yang Y, Tian F. 2009. Abrupt change of runoff and its major driving factors in Haihe River Catchment, China. Journal of Hydrology 374: 373-383. DOI: 10.1016/j.jhydrol.2009.06. 040.

Yuan RQ, Song XF, Zhang YH, Han DM, Wang SQ, Tang CY. 2011. Using major ions and stable isotopes to characterize recharge regime of a fault-influenced aquifer in Beiyishui River Watershed, North China Plain. Journal of Hydrology 405: 512-521. DOI: 10.1016/j.jhydrol.2011.05.048.

Zhang ZJ, Fei YH. 2009. Atlas of Groundwater Sustainable Utilizations in North China Plain. SinoMaps Press, Beijing, China; 185 (in Chinese). 